IZA DP No. 5664

Physical Attractiveness, Employment, and Earnings

Christian Pfeifer

April 2011 


\title{
Physical Attractiveness, Employment, and Earnings
}

\author{
Christian Pfeifer \\ Leuphana University Lüneburg \\ and IZA
}

\section{Discussion Paper No. 5664 \\ April 2011}

\section{IZA}

P.O. Box 7240

53072 Bonn

Germany

Phone: +49-228-3894-0

Fax: +49-228-3894-180

E-mail: iza@iza.org

Any opinions expressed here are those of the author(s) and not those of IZA. Research published in this series may include views on policy, but the institute itself takes no institutional policy positions.

The Institute for the Study of Labor (IZA) in Bonn is a local and virtual international research center and a place of communication between science, politics and business. IZA is an independent nonprofit organization supported by Deutsche Post Foundation. The center is associated with the University of Bonn and offers a stimulating research environment through its international network, workshops and conferences, data service, project support, research visits and doctoral program. IZA engages in (i) original and internationally competitive research in all fields of labor economics, (ii) development of policy concepts, and (iii) dissemination of research results and concepts to the interested public.

IZA Discussion Papers often represent preliminary work and are circulated to encourage discussion. Citation of such a paper should account for its provisional character. A revised version may be available directly from the author. 
IZA Discussion Paper No. 5664

April 2011

\section{ABSTRACT \\ Physical Attractiveness, Employment, and Earnings}

Survey data is used to estimate the impact of physical attractiveness rated by the interviewer as well as by the respondent on employment probability and labor income of men and women. In addition to mean linear and non-linear effects on earnings, simultaneous quantile regressions are applied to analyze heterogeneity across the wage distribution.

JEL Classification: J31, J71, J10

Keywords: attractiveness, beauty, employment, wages

Corresponding author:

Christian Pfeifer

Leuphana University Lüneburg

Scharnhorststr. 1

C4.220b

21335 Lüneburg

Germany

E-mail: pfeifer@leuphana.de 


\section{Introduction}

The impact of beauty, more precisely of subjective perceptions of physical attractiveness, on labor market outcomes has received increasing attention during last years (e.g., Hamermesh and Biddle, 1994; Hamermesh et al., 2002; French, 2002; Mobius and Rosenblat, 2006; Fletcher, 2009). In addition to the naive interest in physical attractiveness and popular discussion of the beauty myth, an economic interest arises in the context of productivity as well as statistical and taste discrimination (Hamermesh and Biddle, 1994). ${ }^{1}$ First, physical attractiveness might be positively correlated with non-cognitive or social skills (e.g., higher self-esteem) and sympathy feelings (e.g., better working climate), which increase workers and co-workers productivity ( $\partial M P L / \partial b>0 ; M P L$ : marginal product of labor, $b$ : beauty or physical attractiveness). As attractiveness is a proxy for such unobserved characteristics, firms might statistical discriminate in favor of more attractive persons and pay them higher wages (labor demand FOC for profit maximizing firm: $w_{b}=p \cdot M P L(b)$ with $\partial w_{b} / \partial b>0$; $w$ : wage). Second, customer taste discrimination increases the value of marginal product of more attractive workers. If customers have a higher willingness to pay for otherwise equal products and services of more attractive persons ( $p_{b}=p+b ; p$ : price, $b$ : beauty premium), firms are likely to employ more attractive workers to increase revenues and profits and can pay them higher wages (FOC: $w_{b}=(p+b) \cdot M P L$ with $\left.\partial w_{b} / \partial b>0\right)$ (Pfann et al., 2000). Third, employer taste discrimination

\footnotetext{
${ }^{1}$ Statistical discrimination in its simplest form implies that firms use signals to reduce uncertainties about workers' individual productivities and consequently prefer to recruit workers who belong to a group with on average more favorable characteristics (Aigner and Cain, 1977). Taste discrimination implies that physical attractiveness of other people enters individual utility functions of customers, employers, or co-workers (Becker, 1971).
} 
can increase employment chances and wages of more attractive people, if an employer is willing to pay higher wages to see more attractive workers in his firm $\left(w_{b}=w+b\right.$ with $\left.\partial w_{b} / \partial b>0\right)$.

In line with the above considerations, previous studies for Canada, China, and the U.S. have indeed found that more attractive people earn on average higher wages (e.g., Hamermesh and Biddle, 1994; Hamermesh et al., 2002; French, 2002; Fletcher, 2009). This research note contributes new microeconometric evidence from German survey data, which comprise information on subjective attractiveness evaluations by the interviewer and the interviewed person. In addition to mean linear wage effects of physical attractiveness, I analyze non-linearity of the wage effect as well as heterogeneity of the effect across the wage distribution. Moreover, this research note looks at the effect of attractiveness on employment probabilities.

\section{Data and Variables}

The used data is the 2008 cross section of a German General Social Survey named ALLBUS (Terwey, 2000). More than 3000 individuals across Germany are asked several questions about employment, income, education, social and political behavior etc. in personal interviews. Of special interest for this study are three variables about the physical attractiveness of the interviewed person. First, the interviewer rates the physical attractiveness of the respondent at the start (first impression) and at the end of an interview. Second, the respondent is asked how he would rate his attractiveness. All three ratings (interviewer at start, interviewer at end, self-rating) have identical coding ranging from one for very unattractive to eleven for very attractive. Even though interviewer ratings as well as self-ratings are subject to a subjectivity bias, they include valuable information because perceived and not objective attractiveness should actually influence 
labor market outcomes. Self-ratings might further suffer from a comparison bias because individuals are likely to choose comparison groups that make them feel better (Falk and Knell, 2004), e.g., average attractive people compare themselves with less attractive people and not with more attractive people. Nevertheless, such self-ratings as proxies for self perceptions are meaningful in the context of non-cognitive skills such as confidence (French, 2002).

Table 1 contains basic descriptive information about the attractiveness variables of employed workers. Differences between interviewer ratings at the start and at the end of an interview are small. Such a comparison is still useful, because it can be seen that the interviewer perceives the respondent on average as slightly more attractive after the interview has been finished. Furthermore, the standard deviations of ratings at end of an interview are smaller suggesting that more extreme first impressions are mitigated during the interview. More impressive are however the differences between interviewer and self-ratings. Respondents perceive themselves on average as significant less attractive than the interviewer does.

\section{- Insert Table 1 about here.}

The dependent variables in the subsequent econometric models are a binary employment status variable, for which a Probit model is applied, and the log monthly net labor income, for which ordinary least squares (OLS) is applied. In addition to the attractiveness variables, the estimates for employment probabilities include a female dummy, secondary schooling and college degrees, age, squared age, and a regional dummy for Eastern Germany. The earnings functions control additionally for ten working hours categories, which is important because the dependent variable is based on monthly income and not on hourly wages. The "employment probability sample" as well as the "earnings sample" contain only German individuals aged between 18 and 65 years. 
The "earnings sample" is further restricted to employed workers with a labor income of at least 400 Euros per month. Descriptive statistics for the "earnings sample" are presented in Table 1.

\section{Econometric Results}

\subsection{Employment Effects}

Table 2 presents absolute marginal effects on the employment probability obtained from binary Probit estimates. The results for attractiveness rated by interviewer at start and end of an interview are virtually identical and jointly discussed (specifications (1) and (2)). A one point higher attractiveness rating on the eleven point scale is associated with an approximately three percentage point higher employment probability. This effect is quite sizeable. A five point difference in attractiveness has for example the same impact as being female or having a college degree. The marginal effects of self-rated attractiveness (specifications (3)) are also positive and significant but about one percentage point smaller in size than effects of interviewer ratings. Separate estimates for men and women show that the effects of all attractiveness variables are positive and significant for both genders and somewhat larger for men than for women.

\section{- Insert Table 2 about here.}

\subsection{Mean Linear Wage Effects}

The results for the log linear earnings functions are presented in Table 3. Since attractiveness enters the earnings functions in a linear fashion, the estimated coefficients are the mean linear 
effects of attractiveness on wages. Attractiveness ratings by interviewer have statistical significant and sizeable positive effects. Workers, who get a one point higher attractiveness rating on the eleven point scale, earn on average about three percent higher monthly income. The rates of return to attractiveness are larger for men than for women. The estimated effects are also larger for interviewer ratings at start (specifications (1)) than at end of an interview (specifications (2)). Self-rated attractiveness has a significant positive effect on female but not on male wages (specifications (3)). Including both interviewer ratings and self-ratings in one equation leads to estimated coefficients that are virtually identical for the interviewer rating at the start of an interview and not significantly different from zero for the two other attractiveness ratings. ${ }^{2}$ The overall results indicate that the first impression other people have about a person's attractiveness are most important in explaining variance of earnings.

\section{- Insert Table 3 about here.}

\subsection{Mean Non-Linear Wage Effects}

The previous earnings regressions for men and women are re-estimated with an additional squared term of the attractiveness rating. Based on these results, predicted log income profiles for an average worker conditional on attractiveness ratings are plotted in Figure 1 for men and in Figure 2 for women. Male profiles are concave and virtually identical for interviewer ratings at start and end of an interview. The concavity implies that wage punishment for unattractiveness is larger than wage premium for attractiveness. This interpretation becomes even stronger if one reconsiders that average male attractiveness rated by interviewer is about 7.8 and hence quite

\footnotetext{
${ }^{2}$ The results of this regression are not included in this note but can be requested from the author.
} 
close to the maximum of the profile. Moreover, interviewer ratings have a larger impact on male earnings than self-ratings. The profiles for women are rather linear and do not differ significantly between the different attractiveness measures. It can also be seen that profiles are steeper for men than for women.

- Insert Figure 1 about here.

- Insert Figure 2 about here.

\subsection{Heterogeneous Wage Effects Across Wage Distribution}

The previous earnings regressions estimated mean wage effects of attractiveness. To extend the perspective on the entire wage distribution, I estimate simultaneous quantile regressions for the $0.05,0.10,0.25,0.50,0.75,0.90$, and 0.95 quantiles based on the complete sample. Table 4 contains the results of the estimated coefficients for attractiveness ratings. ${ }^{3}$ The impact of attractiveness rated by interviewer is slightly larger in higher wage quantiles, whereas the evidence is not clear cut for self-rated attractiveness. The overall results show positive rates of return to attractiveness across the entire wage distribution.

\section{- Insert Table 4 about here.}

\footnotetext{
${ }^{3}$ The complete estimation results can be requested from the author.
} 


\section{Conclusion}

Main results of this research note are: (1) More attractive people are on average more likely to be employed and earn on average higher wages. The effects are statistically significant and quite sizeable. (2) The estimated effects of interviewer ratings are in general larger for men than for women, whereas self-ratings have larger effects among women. (3) Attractiveness rated by other people, in our case the interviewer, has a larger impact than self-rated attractiveness. (4) The wage effects of attractiveness are non-linear for men, which implies that wage punishment for unattractiveness is larger than wage premium for attractiveness, and linear for women. (5) The wage effects of attractiveness are positive across the entire wage distribution. 


\section{References}

Aigner, G.J. and G.G. Cain, 1977, Statistical theories of discrimination in labor markets, Industrial and Labor Relations Review 30, 175-187.

Becker, G.S., 1971, The economics of discrimination, 2nd edition, Chicago: University of Chicago Press.

Falk, A. and M. Knell, 2004, Choosing the Joneses: endogenous goals and reference standards, Scandinavian Journal of Economics 106, 417-435.

Fletcher, J.M., 2009, Beauty vs. brains: early labor market outcomes of high school graduates, Economics Letters 105, 321-325.

French, M.T., 2002, Physical appearance and earnings: further evidence, Applied Economics 34, 569-572.

Hamermesh, D.S. and J.E. Biddle, 1994, Beauty and the labor market, American Economic Review 84, 1174-1194.

Hamermesh, D.S., Meng, X., and J. Zhang, 2002, Dress for success - does primping pay?, Labour Economics 9, 361-373.

Mobius, M.M. and T.S. Rosenblat, 2006, Why beauty matters, American Economic Review 96, 222-235.

Pfann, G.A., Biddle, J.E., Hamermesh, D.S., and C.M. Bosman, 2000, Business success and businesses' beauty capital, Economics Letters 67, 201-207.

Terwey, M., 2000, ALLBUS: A German General Social Survey, Schmollers Jahrbuch 120, 151158. 


\section{Tables and Figure included in Text}

Table 1: Descriptive statistics for "earnings sample"

\begin{tabular}{|c|c|c|c|c|c|c|}
\hline & \multicolumn{2}{|c|}{ All $(n=1224)$} & \multicolumn{2}{|c|}{ Men $(\mathrm{n}=692)$} & \multicolumn{2}{|c|}{ Women $(\mathrm{n}=532)$} \\
\hline & Mean & Std. Dev. & Mean & Std. Dev. & Mean & Std. Dev. \\
\hline Log of monthly net labor income (log Euros) & 7.3118 & 0.5509 & 7.4720 & 0.5370 & 7.1036 & 0.4969 \\
\hline Attractiveness - rated by interviewer at start (1: low, 11: high) & 7.9191 & 1.7569 & 7.7558 & 1.7440 & 8.1316 & 1.7525 \\
\hline Attractiveness - rated by interviewer at end (1: low, 11: high) & 7.9894 & 1.6938 & 7.8454 & 1.6532 & 8.1767 & 1.7290 \\
\hline Attractiveness - self-rated by respondent (1: low, 11: high) & 7.1217 & 1.7914 & 7.0434 & 1.7887 & 7.2237 & 1.7916 \\
\hline Female (Dummy) & 0.4346 & 0.4959 & 0.0000 & 0.0000 & 1.0000 & 0.0000 \\
\hline Schooling degree medium ("Realschule") (Dummy) & 0.4191 & 0.4936 & 0.3931 & 0.4888 & 0.4530 & 0.4983 \\
\hline Schooling degree high ("Gymnasium") (Dummy) & 0.3538 & 0.4783 & 0.3512 & 0.4777 & 0.3571 & 0.4796 \\
\hline College degree (Dummy) & 0.2402 & 0.4274 & 0.2413 & 0.4282 & 0.2387 & 0.4267 \\
\hline Age in years & 43.0833 & 11.3467 & 43.0130 & 11.5684 & 43.1748 & 11.0620 \\
\hline Age squared / 100 & 19.8482 & 9.4565 & 19.8375 & 9.6064 & 19.8620 & 9.2669 \\
\hline East Germany (Dummy) & 0.3105 & 0.4629 & 0.2876 & 0.4530 & 0.3402 & 0.4742 \\
\hline
\end{tabular}


Table 2: Attractiveness and employment probability (Probit, marginal effects)

\begin{tabular}{|c|c|c|c|c|c|c|c|c|c|}
\hline & (1) All & (1) Men & (1) Women & (2) All & (2) Men & (2) Women & (3) All & (3) Men & (3) Women \\
\hline Attractiveness - interviewer at start & $\begin{array}{c}0.0307 * * * \\
(0.0057)\end{array}$ & $\begin{array}{c}0.0329 * * * \\
(0.0070)\end{array}$ & $\begin{array}{c}0.0263^{* * *} \\
(0.0085)\end{array}$ & & & & & & \\
\hline Attractiveness - interviewer at end & & & & $\begin{array}{c}0.0337 * * * \\
(0.0058)\end{array}$ & $\begin{array}{c}0.0376 * * * \\
(0.0071)\end{array}$ & $\begin{array}{c}0.0266^{* * *} \\
(0.0086)\end{array}$ & & & \\
\hline Attractiveness - self-rated & & & & & & & $\begin{array}{c}0.0215^{* * *} \\
(0.0056)\end{array}$ & $\begin{array}{c}0.0258^{* * *} \\
(0.0071)\end{array}$ & $\begin{array}{l}0.0148 * \\
(0.0083)\end{array}$ \\
\hline Female & $\begin{array}{c}-0.1747 * * * \\
(0.0201)\end{array}$ & & & $\begin{array}{c}-0.1766^{* * *} \\
(0.0201)\end{array}$ & & & $\begin{array}{c}-0.1672 * * * \\
(0.0203)\end{array}$ & & \\
\hline Schooling medium & $\begin{array}{c}0.0923 * * * \\
(0.0252)\end{array}$ & $\begin{array}{c}0.0674 * * \\
(0.0318)\end{array}$ & $\begin{array}{c}0.1287 * * * \\
(0.0383)\end{array}$ & $\begin{array}{c}0.0895 * * * \\
(0.0253)\end{array}$ & $\begin{array}{l}0.0613 * \\
(0.0318)\end{array}$ & $\begin{array}{c}0.1295^{* * *} \\
(0.0382)\end{array}$ & $\begin{array}{c}0.0960 * * * \\
(0.0254)\end{array}$ & $\begin{array}{c}0.0657 * * \\
(0.0322)\end{array}$ & $\begin{array}{c}0.1365 * * * \\
(0.0381)\end{array}$ \\
\hline Schooling high & $\begin{array}{l}-0.0047 \\
(0.0322)\end{array}$ & $\begin{array}{l}-0.0617 \\
(0.0420)\end{array}$ & $\begin{array}{c}0.0777 \\
(0.0475)\end{array}$ & $\begin{array}{l}-0.0069 \\
(0.0322)\end{array}$ & $\begin{array}{l}-0.0621 \\
(0.0418)\end{array}$ & $\begin{array}{c}0.0755 \\
(0.0477)\end{array}$ & $\begin{array}{c}0.0080 \\
(0.0318)\end{array}$ & $\begin{array}{l}-0.0436 \\
(0.0415)\end{array}$ & $\begin{array}{l}0.0865 * \\
(0.0472)\end{array}$ \\
\hline College & $\begin{array}{c}0.1736^{* * *} \\
(0.0266)\end{array}$ & $\begin{array}{c}0.1574 * * * \\
(0.0286)\end{array}$ & $\begin{array}{c}0.1829 * * * \\
(0.0452)\end{array}$ & $\begin{array}{c}0.1708 * * * \\
(0.0268)\end{array}$ & $\begin{array}{c}0.1518 * * * \\
(0.0290)\end{array}$ & $\begin{array}{c}0.1836^{* * *} \\
(0.0450)\end{array}$ & $\begin{array}{c}0.1766 * * * \\
(0.0267)\end{array}$ & $\begin{array}{c}0.1586^{* * *} \\
(0.0293)\end{array}$ & $\begin{array}{c}0.1906 * * * \\
(0.0448)\end{array}$ \\
\hline Age in years & $\begin{array}{c}0.0720 * * * \\
(0.0050)\end{array}$ & $\begin{array}{c}0.0671^{* * *} \\
(0.0059)\end{array}$ & $\begin{array}{c}0.0718^{* * *} \\
(0.0084)\end{array}$ & $\begin{array}{c}0.0729 * * * \\
(0.0051)\end{array}$ & $\begin{array}{c}0.0684 * * * \\
(0.0059)\end{array}$ & $\begin{array}{c}0.0721 * * * \\
(0.0084)\end{array}$ & $\begin{array}{c}0.0730 * * * \\
(0.0051)\end{array}$ & $\begin{array}{c}0.0701^{* * *} \\
(0.0060)\end{array}$ & $\begin{array}{c}0.0701 * * * \\
(0.0084)\end{array}$ \\
\hline Age squared / 100 & $\begin{array}{c}-0.0889 * * * \\
(0.0059)\end{array}$ & $\begin{array}{c}-0.0844 * * * \\
(0.0070)\end{array}$ & $\begin{array}{c}-0.0865^{* * *} \\
(0.0096)\end{array}$ & $\begin{array}{c}-0.0899 * * * \\
(0.0059)\end{array}$ & $\begin{array}{c}-0.0858 * * * \\
(0.0070)\end{array}$ & $\begin{array}{c}-0.0870 * * * \\
(0.0096)\end{array}$ & $\begin{array}{c}-0.0905^{* * *} \\
(0.0060)\end{array}$ & $\begin{array}{c}-0.0883 * * * \\
(0.0071)\end{array}$ & $\begin{array}{c}-0.0850 * * * \\
(0.0097)\end{array}$ \\
\hline East Germany & $\begin{array}{c}-0.1040 * * * \\
(0.0234)\end{array}$ & $\begin{array}{c}-0.1569 * * * \\
(0.0310)\end{array}$ & $\begin{array}{l}-0.0419 \\
(0.0341)\end{array}$ & $\begin{array}{c}-0.1029 * * * \\
(0.0234)\end{array}$ & $\begin{array}{c}-0.1518^{* * *} \\
(0.0309)\end{array}$ & $\begin{array}{l}-0.0428 \\
(0.0342)\end{array}$ & $\begin{array}{c}-0.1073 * * * \\
(0.0236)\end{array}$ & $\begin{array}{c}-0.1619 * * * \\
(0.0315)\end{array}$ & $\begin{array}{c}-0.0437 \\
(0.0342)\end{array}$ \\
\hline $\begin{array}{l}\text { Predicted employment } \\
\text { probability at means }\end{array}$ & 0.7236 & 0.8062 & 0.6351 & 0.7245 & 0.8083 & 0.6352 & 0.7207 & 0.8028 & 0.6341 \\
\hline Pseudo R² & 0.1607 & 0.1992 & 0.1166 & 0.1630 & 0.2045 & 0.1169 & 0.1534 & 0.1951 & 0.1082 \\
\hline Number of observations & 2201 & 1135 & 1066 & 2201 & 1135 & 1066 & 2158 & 1110 & 1048 \\
\hline
\end{tabular}

Notes: Binary ML-Probit, marginal effects at means. Standard errors in parentheses. Marginal effects significant at * $10 \%$, ** 5\%, and *** $1 \%$. 
Table 3: Attractiveness and income (OLS, mean linear effects)

\begin{tabular}{|c|c|c|c|c|c|c|c|c|c|}
\hline & (1) All & (1) Men & (1) Women & (2) All & (2) Men & (2) Women & (3) All & (3) Men & (3) Women \\
\hline Attractiveness - interviewer at start & $\begin{array}{c}0.0338 * * * \\
(0.0068)\end{array}$ & $\begin{array}{c}0.0403^{* * *} \\
(0.0091)\end{array}$ & $\begin{array}{l}0.0233 * * \\
(0.0102)\end{array}$ & & & & & & \\
\hline Attractiveness - interviewer at end & & & & $\begin{array}{c}0.0288^{* * *} \\
(0.0074)\end{array}$ & $\begin{array}{c}0.0344^{* * * *} \\
(0.0104)\end{array}$ & $\begin{array}{l}0.0189 * \\
(0.0105)\end{array}$ & & & \\
\hline Attractiveness - self-rated & & & & & & & $\begin{array}{c}0.0131^{* *} \\
(0.0066)\end{array}$ & $\begin{array}{c}0.0114 \\
(0.0087)\end{array}$ & $\begin{array}{c}0.0197 * * \\
(0.0099)\end{array}$ \\
\hline Female & $\begin{array}{c}-0.1968 * * * \\
(0.0250)\end{array}$ & & & $\begin{array}{c}-0.1953 * * * \\
(0.0252)\end{array}$ & & & $\begin{array}{c}-0.1875 * * * \\
(0.0252)\end{array}$ & & \\
\hline Schooling medium & $\begin{array}{c}0.1179 * * * \\
(0.0310)\end{array}$ & $\begin{array}{l}0.0803 * \\
(0.0412)\end{array}$ & $\begin{array}{c}0.2061 * * * \\
(0.0452)\end{array}$ & $\begin{array}{c}0.1214^{* * *} \\
(0.0310)\end{array}$ & $\begin{array}{l}0.0788 * \\
(0.0413)\end{array}$ & $\begin{array}{c}0.2124 * * * \\
(0.0454)\end{array}$ & $\begin{array}{c}0.1319^{* * *} \\
(0.0309)\end{array}$ & $\begin{array}{c}0.0894 * * \\
(0.0414)\end{array}$ & $\begin{array}{c}0.2215^{* * *} \\
(0.0447)\end{array}$ \\
\hline Schooling high & $\begin{array}{c}0.1596 * * * \\
(0.0392)\end{array}$ & $\begin{array}{c}0.1246 * * \\
(0.0542)\end{array}$ & $\begin{array}{c}0.2409 * * * \\
(0.0543)\end{array}$ & $\begin{array}{c}0.1636 * * * \\
(0.0392)\end{array}$ & $\begin{array}{l}0.1343 * * \\
(0.0540)\end{array}$ & $\begin{array}{c}0.2403 * * * \\
(0.0546)\end{array}$ & $\begin{array}{c}0.1764^{* * *} \\
(0.0386)\end{array}$ & $\begin{array}{c}0.1538 * * * \\
(0.0531)\end{array}$ & $\begin{array}{c}0.2454 * * * \\
(0.0536)\end{array}$ \\
\hline College & $\begin{array}{c}0.3217 * * * \\
(0.0392)\end{array}$ & $\begin{array}{c}0.3155^{* * *} \\
(0.0527)\end{array}$ & $\begin{array}{c}0.3226 * * * \\
(0.0587)\end{array}$ & $\begin{array}{c}0.3213^{* * *} \\
(0.0393)\end{array}$ & $\begin{array}{c}0.3111^{* * *} \\
(0.0529)\end{array}$ & $\begin{array}{c}0.3255^{* * *} \\
(0.0590)\end{array}$ & $\begin{array}{c}0.3313^{* * *} \\
(0.0390)\end{array}$ & $\begin{array}{c}0.3152^{* * *} \\
(0.0525)\end{array}$ & $\begin{array}{c}0.3327 * * * \\
(0.0586)\end{array}$ \\
\hline Age in years & $\begin{array}{c}0.0530 * * * \\
(0.0074)\end{array}$ & $\begin{array}{c}0.0654^{* * *} \\
(0.0096)\end{array}$ & $\begin{array}{c}0.0307^{* * *} \\
(0.0113)\end{array}$ & $\begin{array}{c}0.0528 * * * \\
(0.0074)\end{array}$ & $\begin{array}{c}0.0653^{* * *} \\
(0.0096)\end{array}$ & $\begin{array}{c}0.0303 * * * \\
(0.0113)\end{array}$ & $\begin{array}{c}0.0534 * * * \\
(0.0074)\end{array}$ & $\begin{array}{c}0.0650 * * * \\
(0.0097)\end{array}$ & $\begin{array}{c}0.0307 * * * \\
(0.0113)\end{array}$ \\
\hline Age squared / 100 & $\begin{array}{c}-0.0497 * * * \\
(0.0089)\end{array}$ & $\begin{array}{c}-0.0613 * * * \\
(0.0116)\end{array}$ & $\begin{array}{c}-0.0277 * * \\
(0.0136)\end{array}$ & $\begin{array}{c}-0.0497 * * * \\
(0.0089)\end{array}$ & $\begin{array}{c}-0.0612 * * * \\
(0.0116)\end{array}$ & $\begin{array}{c}-0.0275^{* *} \\
(0.0136)\end{array}$ & $\begin{array}{c}-0.0511 * * * \\
(0.0089)\end{array}$ & $\begin{array}{c}-0.0616 * * * \\
(0.0118)\end{array}$ & $\begin{array}{c}-0.0281 * * \\
(0.0135)\end{array}$ \\
\hline East Germany & $\begin{array}{c}-0.2958^{* * *} \\
(0.0262)\end{array}$ & $\begin{array}{c}-0.3543 * * * \\
(0.0364)\end{array}$ & $\begin{array}{c}-0.2323 * * * \\
(0.0377)\end{array}$ & $\begin{array}{c}-0.2904^{* * *} \\
(0.0262)\end{array}$ & $\begin{array}{c}-0.3432 * * * \\
(0.0367)\end{array}$ & $\begin{array}{c}-0.2303^{* * *} \\
(0.0377)\end{array}$ & $\begin{array}{c}-0.2859 * * * \\
(0.0264)\end{array}$ & $\begin{array}{c}-0.3420 * * * \\
(0.0373)\end{array}$ & $\begin{array}{c}-0.2270^{* * *} \\
(0.0377)\end{array}$ \\
\hline Ten working hours categories & Yes & Yes & Yes & Yes & Yes & Yes & Yes & Yes & Yes \\
\hline Constant & $\begin{array}{c}5.1741 * * * \\
(0.1709)\end{array}$ & $\begin{array}{c}4.9619 * * * \\
(0.2713)\end{array}$ & $\begin{array}{c}5.4844 * * * \\
(0.2373)\end{array}$ & $\begin{array}{c}5.2151^{* * *} \\
(0.1700)\end{array}$ & $\begin{array}{c}5.0105^{* * *} \\
(0.2631)\end{array}$ & $\begin{array}{c}5.5281 * * * \\
(0.2395)\end{array}$ & $\begin{array}{c}5.3342^{* * *} \\
(0.1733)\end{array}$ & $\begin{array}{c}5.2012^{* * *} \\
(0.2750)\end{array}$ & $\begin{array}{c}5.5283 * * * \\
(0.2345)\end{array}$ \\
\hline $\mathrm{R}^{2}$ & 0.5032 & 0.4746 & 0.4367 & 0.4998 & 0.4691 & 0.4345 & 0.4944 & 0.4602 & 0.4356 \\
\hline Adjusted R² & 0.4962 & 0.4621 & 0.4192 & 0.4927 & 0.4565 & 0.4170 & 0.4873 & 0.4474 & 0.4180 \\
\hline Number of observations & 1224 & 692 & 532 & 1224 & 692 & 532 & 1224 & 692 & 532 \\
\hline
\end{tabular}

Notes: Log-linear earnings functions with OLS, coefficients. Standard errors in parentheses. Coefficients significant at * $10 \%$, ** 5\%, and $* * * 1 \%$. 


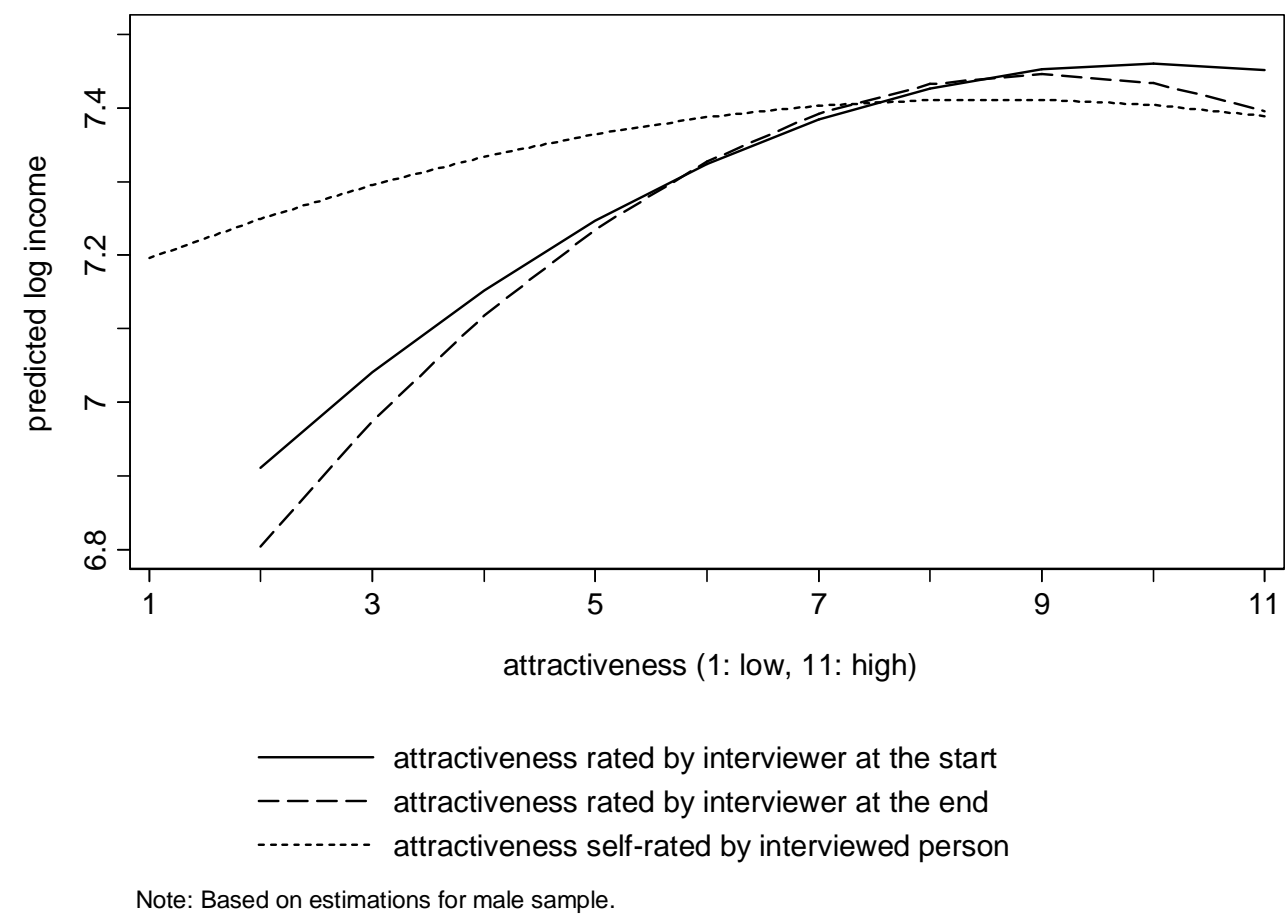

Figure 1: Attractiveness and income for men (OLS, mean non-linear effects) 


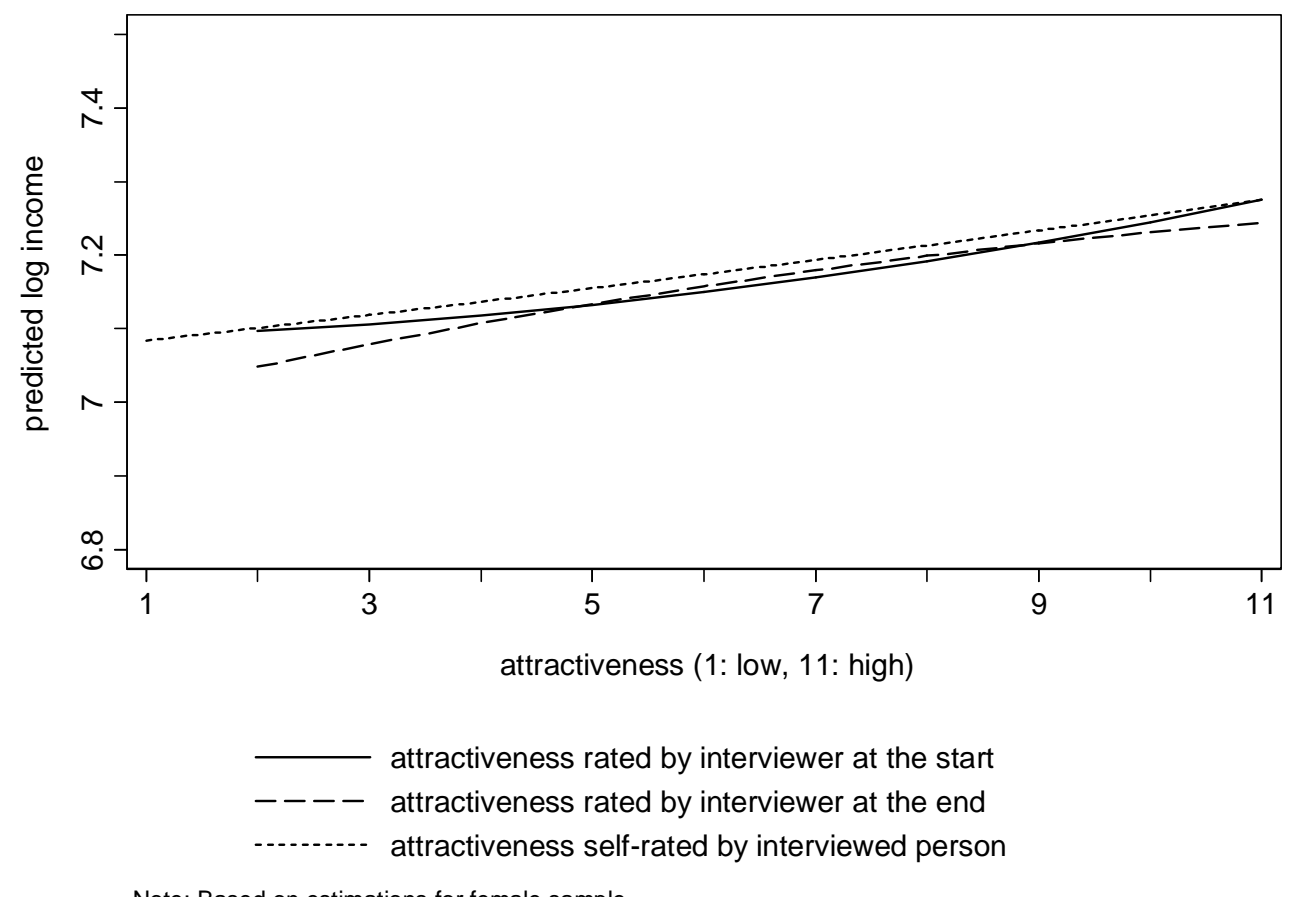

Figure 2: Attractiveness and income for women (OLS, mean non-linear effects) 
Table 4: Attractiveness and income across the wage distribution (simultaneous quantile regressions)

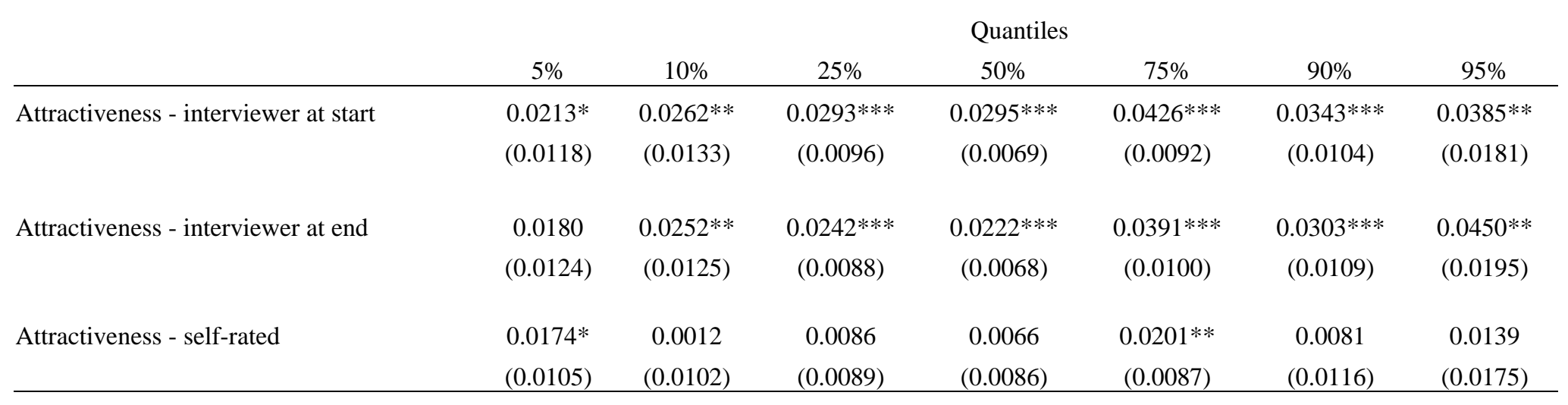

Notes: Simultaneous quantile regressions for complete sample $(n=1224)$, separately for different attractiveness variables, coefficients. All regressions control for gender, secondary schooling and college degrees, age, squared age, East Germany, eleven working hours categories. Bootstrapped standard errors with 100 replications in parentheses. Coefficients significant at * 10\%, ** 5\%, and *** $1 \%$. 